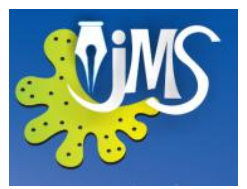

\title{
Optimization of Palmyrah (Borrasus flabellifer) Fruit Pulp in Different Varieties of Fruit Yoghurts
}

\author{
S. Sangheetha ${ }^{1}$, M. A. J. Wansapala ${ }^{2}$, A. Gnanasharmala ${ }^{1}$, S. Srivijeindran ${ }^{1}$ \\ ${ }^{1}$ Palmyrah Research Institute, Kandy Road, Kaithady, Sri Lanka \\ ${ }^{2}$ Department of Food Science and Technology, Faculty of Applied Sciences, \\ University of Sri Jayewardenepura, Nugegoda, Sri Lanka
}

\begin{abstract}
The research focused on processing palmyrah fruit pulp into a value added product to broaden the utilization of palmyrah fruit pulp. Set, swiss style, jelly and pulp preserve yoghurts incorporated with palmyrah fruit pulp were developed. Control yoghurt and plain yoghurt for other preparations were prepared with $13 \%$ sugar, $1 \%$ gelatin, $12 \%$ skim milk powder and lactic acid bacteria culture following household method. The fresh pulp was kept at - 25 oC for 48 hours and heated up to 85 oC for 30 minutes with $5 \%$ cane sugar, 0.6 $\%$ tartaric acid, $1 \%$ ascorbic acid and $0.13 \%$ sodium chloride. The treated pulp was added at $5 \%, 7.5 \%$, $10 \%, 12.5 \%$ and $15 \%$ into both set and swiss style yoghurts. Fruit jelly was prepared with sugar, gelatin, sodium citrate, citric acid and $20 \%$ pulp. It was then incorporated into yoghurt at $5 \%$ and $6 \%$. Palmyrah fruit pulp preserve was prepared by heating sugar, pectin and pulp (45. $8 \%$ ) until its brix reached $68.5 \mathrm{o}$ and it was topped on set yoghurt at $5 \%, 7.5 \%$ and $10 \%$. Sensory evaluation for colour, odour, appearance, mouth feel and texture was conducted with 21 untrained panelists using 5 point hedonic scale and the optimized pulp concentrations for set, swiss style, jelly and preserve yoghurt were $5 \%, 7.5 \%, 6 \%$ and $10 \%$ respectively $(p<0.05)$. The overall sensory qualities of all palmyrah fruit yoghurts were rated as good to very good. There were no significant changes in sensory attributes, brix and $\mathrm{pH}$ in storage at $4 \mathrm{oC}$. Shelf life was 18 days for all products at 4 oC without any preservatives except set yoghurt as it showed separation of water from the third day of the preparation. Nutritional and microbiological qualities of the products were investigated and compared with control yoghurt. Protein was higher in swiss style (6.12\%) and jelly (7.77 $\%)$ yoghurts. Carbohydrate was higher in swiss style yoghurt (36.87\%) and preserve yoghurt contained highest fat content $(2.57 \%)$.
\end{abstract}

Keywords: Carbohydrate, fruit yoghurt, palmyrah fruit, pulp, protein 


\section{INTRODUCTION}

Palmyrah (Borrasus flabellifer) possess a great capacity to yield several products of economic importance and hence it is called "Wishing tree" which means a palm that yields anything and everything. Almost every part of the palm is utilized but most of the products from the palm are made by traditional methods known from the time immemorial.

It is estimated from the statistical data of existing female palms in Sri Lanka that, about 20,000 tons of palmyrah fruit pulp is available annually during fruit season but around 10000 tons of pulp is thrown in to nature or used for animal feeding (Jansz et al 2002) every year because its uses are limited mainly due to the presence of a bitter compound and lack of trials are done to process into various consumer attractive value added products.

Moreover, palmyrah fruit pulp is nutritious and has a yellow colour due to carotenoids which are precursors of vitamin A and therefore it has potential of being as a source of vitamin A and giving attractive yellow colour to foods. In addition to that, it is revealed that pulp is rich in vitamin $\mathrm{C}$ (ascorbic acid) and a good source of pectin which could be used to process the fruits into various products (Theivendrarajah, 2008)

With regard to palmyrah plantation, it is reported that currently 24.260 hectares equivalent with 11 million palms are available of which 3.5 million trees are in Jaffna, 3.5 million in Kilinochchi, 3 million in Mannar and balance scattered all over the country (Palmyrah development board 2010). Government's Mahinda Chintana 10 - year plan aims to increase the current level of palms from 11 million to 16 million by 2016 and the vision of it for the future strongly emphasizes on the need to promote palmyrah based products including its fruits. Also the government has given high priority for dairy development (Ministry of livestock and rural community development, 2010). Currently major part of milk production is done by farmers domestically and their life is as same as that of palmyrah dependents.

The above facts generated the idea to produce a value added consumer attractive product using palmyrah fruit pulp and milk. As a result the research was conducted with the aims of developing formulae for different kinds of palmyrah fruit yoghurts, analyzing nutrient contents of the yoghurts and determining shelf lives of them. The research, when industrialized will give the benefits to the palmyrah dependents of approximately $1 / 3^{\text {rd }}$ of the population of Northern and Eastern provinces where palmyrah occurs extensively by increasing the marketing and utilization of palmyrah fruit pulp, minimizing the wastage of a nutritive resource and under exploitation of the health aspects of pulp and employment opportunities to produce novel product for consumers.

\section{BACKGROUND}

Yoghurt is a healthy and delicious fermented milk product due to its nutritive and therapeutic value with a custard-like consistency which differentiates it from other fermented milk products (Perdigon et al 2002). The Codex Alimentarious Commission (2008) defines it as a coagulated milk product obtained by lactic acid fermentation through the action of Lactobacillus bulgaricus and Streptococcus 
thermophilus from milk with or without additions and the microorganisms in the final product must be viable and abundant.

Yoghurt is commonly considered as safer product and nutritionists are being considering incorporating inexpensive source of nutrient to make it an almost complete food (Boghra and Mathur 2002). Yoghurt is easily digestible and palatable than milk as it contains less lactose. Further, it is treasured for controlling the growth of bacteria and in curing of intestinal disease, for instance, constipation and diarrhea, lowering of blood cholesterol and anti-carcinogenic effect (Kamruzzaman et al 2002). Yoghurt is a great source of B vitamins, phosphorus and calcium. Organoleptic properties such as flavour, texture and aroma of yoghurt depend upon so many factors including the raw materials, manufacturing process and the bacterial strains used (Kumar and Mishra 2004).

According to the Sri Lankan Standard for yoghurts (SLS 824 Part 2:1989) a standard yoghurt should be smooth, glossy surface, no crack or holes on the top, no whey synersis, no off flavor or odor and clean layer on the surface of the yoghurt. It also says that yoghurt must contain minimum of $3.0 \%$ fat whilst it categorizes the yoghurt that contains between $0.5 \%$ and $3.0 \%$ fat as low fat yoghurt and that with less than $0.5 \%$ fat is non-fat yoghurt.

Palmyrah fruit pulp has bitter taste due to flabelliferins and it gives a negative impact on utilization of pulp. Despite that from the point of health, palmyrah fruit pulp has numerous benefits to us. It is now proved that flabelliferins lowers the glucose absorption into blood, increase the cardiac anti oxidant activity and decrease the blood cholesterol. Recent studies show that pulp is rich in provitamin A (32 ppm), vitamin C (285 ppm) (Jeyaratnam 1986) and contains lycopene as well (Pathberiya and Chandrika 2003). Lycopene is an anti oxidant which is beneficial in cardiovascular ailments and cancer.

\section{MATERIALS AND METHODOLOGY}

\subsection{Materials}

Fresh milk was procured from Yarlco, the only dairy production unit in Jaffna peninsula and cream separation was done there using their cream separator. Other ingredients were collected from Jaffna market. Palmyrah fruits were collected from Kopay and Navatkuli.

Reagents used for chemical and microbiological analysis of the developed products were purchased from Sigma Aldrich. All glassware were obtained from ISO certified companies in United Kingdom and Germany and the equipment used for the studies were caliberated and made in United Stated of America and Germany.

\subsection{Quality tests and preparation of raw materials}

Selection and quality of raw materials are the major determinants of the quality of end products in a processing. Therefore raw materials are analyzed prior to be subjected to the processing to ensure the production of good quality end product. In the study, raw milk was subjected to clot boiling test with $68 \%$ alcohol according to COMESA/East African Standards. Also the $\mathrm{pH}$, titrable acidity as lactic acid, total soluble solid, fat and solid non fat of milk were 
determined. It was boiled up to $80{ }^{\circ} \mathrm{C}$ for 15 minutes.

Pest attack free, fresh, black skinned, well ripe fruits were selected to the study. The nutlets were dipped in warm water $\left(45-50{ }^{\circ} \mathrm{C}\right)$ for few seconds and then macerated. The ratio of pulp: added water was 1:0.5 (v/v). Pulp was then strained through a muslin cloth. It was kept in deep freezer at $-25{ }^{\circ} \mathrm{C}$ for about 48 hours.

Palmyrah fruit pulp was treated with 5 $\%$ sugar, $0.6 \%$ tartaric acid, $1 \%$ ascorbic acid, $0.2 \%$ citric acid, $0.13 \%$ sodium chloride and 1 $\%$ gelatin and the mixture was heated up to 85 ${ }^{\circ} \mathrm{C}$ for 30 minutes to incorparate into set and swiss style palmyrah fruit pulp yoghurts.

For jelly yoghurt, palmyrah fruit pulp jelly was prepared with sugar $(84 \%)$, gelatin $(11.5 \%)$, tartaric acid $(1.06 \%)$, sodium citrate $(0.18 \%)$, water and $20 \%$ pulp following the house hold method. Sugar $(53 \%)$ and pectin $(0.35 \%)$ were heated together with the pulp $(45.8 \%)$ were heated until brix reached $68.5^{\circ}$ to prepare fruit preserve for fruit preserve yoghurt. The preserve was prepared freshy in each preparation, so that it can eaisly be poured on the yogurt easily before it gets set.

\subsection{Preparation of yoghurts}

For the plain yoghurt for all four products, 13 $\%$ sugar, $1 \%$ gelatin and $12 \%$ skim milk powder were added and the amounts of them were same in all products. The house hold method for yogurt production was used to prepare yoghurt using lacitic acid bacteira culture procured from Jamma. The preparation of yoghurt, its processing conditions and ingredients were kept same in the preparation of all products.
Optimization of pulp in set and swiss style yoghurts Five recipes in each category of yoghurts were developed for palmyrah fruit pulp incorporated set fruit yoghurt and swiss style yoghurt (Table 1).

TABLE 1: Optimization of fruit pulp concentrations in palmyrah fruit pulp set yoghurt and swiss style yoghurt

\begin{tabular}{|c|c|c|c|c|c|}
\hline \multirow{2}{*}{} & \multicolumn{5}{|c|}{ Treatments } \\
\cline { 2 - 6 } & 1 & 2 & 3 & 4 & 5 \\
\hline $\begin{array}{c}\text { Treated } \\
\text { fruit pulp } \\
\text { amounts } \\
\left(\mathrm{g} 100 \mathrm{ml}^{-1}\right)\end{array}$ & 5.00 & 7.50 & 10.00 & 12.50 & 15.00 \\
\hline
\end{tabular}

Optimization of pulp as jelly in fruit jelly yoghurt Two recipes of palmyrah fruit pulp jelly yogurts were prepared by blending the jelly in different percentages (Table 2). All ingredients except jelly were kept constant in all blends.

TABLE 2: Optimization of palmyrah fruit pulp jelly in swiss style yoghurt

\begin{tabular}{|c|c|}
\hline Treatment & $\begin{array}{c}\text { Pulp in the jelly added to the } \\
\text { product }\left(\mathbf{~} \mathbf{1 0 0} \mathbf{~ m l}^{\mathbf{1}}\right)\end{array}$ \\
\hline 1 & 5.0 \\
\hline 2 & 6.0 \\
\hline
\end{tabular}

\section{Optimization of pulp as preserve in fruit preserve yoghurt}

Three recipes of palmyrah fruit pulp preserve incorporated set yoghurts were prepared. Table 3 shows the percentage of palmyrah fruit pulp preserve added in each treatment. The preserve was poured on the set yogurt. All ingredients 
except fruit pulp preserve were kept constant in all blends.

TABLE 3: Optimization of palmyrah fruit preserve in palmyrah fruit preserve yoghurt

\begin{tabular}{|c|c|}
\hline Treatment & $\begin{array}{l}\text { Pulp in the product } \\
\qquad\left({\left.\mathrm{g} 100 \mathrm{ml}^{-1}\right)}\right.\end{array}$ \\
\hline 1 & 5.0 \\
\hline 2 & 7.5 \\
\hline 3 & 10.0 \\
\hline
\end{tabular}

Selection of the formula of each variety of prepared yoghurts

The formula in each variety of yoghurts which gained most consumer preference was selected via sensory evaluation conducted by 21 untrained panelists using 5 point hedonic scale method and analysis of variance was conducted on the sample means for flavor, colour, mouth feel, appearance, texture and over all acceptability. Statistically significant attributes were further analyzed to see where mean difference existed using Minitab (Friedman test) at $95 \%$ confidence interval $(\mathrm{P}<0.05)$.

\subsection{Analysis of selected yoghurts}

All selected products were subjected to the following tests and the results were then compared with that of control yoghurt.

\section{Chemical analysis}

$\mathrm{pH}$, total soluble solids, and titrable acidity were analyzed according to SLS 824: Part 2, 1989. Crude protein, moisture, crude fat, crude fibre, ash and total carbohydrate were determined in accordance with Association of Analytical Chemists Standard (2002). Same was done for commercially available plain yoghurt as control and compared with developed palmyrah fruit yoghurts.

\section{Microbiological analysis}

Total plate count and yeast and mold were tested for skim milk powder, sugar, milk, water and milk solution prior to the addition of culture. E. coli, yeast and mold in the selected products were assessed according to SLS 824 Part 2: 1989. Same was done for commercially available plain yoghurt.

\section{Shelf life study}

For the shelf life evaluation $\mathrm{pH}$, brix and titrable acidity were measured once in in three days for 21 days. At the same time, texture, appearance, colour, smell and air bubble formation on the surface of the product were observed by experienced persons at the station where the research was carried out.

Experimental design and statistical analysis Friedman non parametric statistical method was used to analyze the results of sensory evaluation data at $95 \%$ confidence level was considered.

\section{RESULTS EVALUATION AND DATA ANALYSIS}

\subsection{Quality tests and preparation of raw materials}

The analysis showed that the raw milk met the quality requirements specified in SLS 824: Part 2: 1989 for yogurt preparation. In Table 4 the fat, solid non fat, density, $\mathrm{pH}$ and acidity of the purcehased milk are given in ranges because the milk was procured three times throughout the studies and the tests for fat, solid non fat and 
density of raw milk were carried out for each batch.

TABLE 4: Quality parameters (fat, solid non fat, density, $\mathrm{pH}$ and acidity) of raw milk used for the study

\begin{tabular}{|l|l|}
\hline \multicolumn{1}{|c|}{$\begin{array}{c}\text { Constituent of } \\
\text { raw milk }\end{array}$} & \multicolumn{1}{|c|}{ Range } \\
\hline Fat & $0.02-0.03{\mathrm{~g} 100 \mathrm{~g}^{-1}}^{-1}{\mathrm{~g} 100 \mathrm{~g}^{-1}}^{-1}$ \\
\hline Solid non fat & $7.5-7.6$ \\
\hline Density & $28.6-29.1$ \\
\hline $\mathrm{pH}$ & $6.6-6.7$ \\
\hline acidity & $0.14-0.17{\mathrm{~g} 100 \mathrm{~g}^{-1}}$ \\
\hline
\end{tabular}

Clot boiling test is carried out to ensure the quality of milk. In the test poor quality milk will coagulate and fine particles of curd will be visible whereas the quality milk will not give so. When the acidity of milk exceeds $0.21 \%$ the milk get spoiled and is not good for the production. The raw milk used in the study did not clot in the alcohol test and the $\mathrm{pH}$ and acidity were ranged $6.6-6.7$ and $0.14-0.17 \%$ respectively which fell into the acceptable ranges of $\mathrm{pH}$ and acidity for consumption.

\section{Fruit pulp preparation}

It would be better if some parameters such as penetration ability, $\mathrm{pH}$ and total soluble solids are standardized for the selection of good quality fruits as it will be more beneficial and easy to the industries to select super grade fruits for the production. Palmyrah fruit pulp was collected and kept in at $-25{ }^{\circ} \mathrm{C}$ till used in order to preserve and minimize the bitterness of pulp.

Therefore the $\mathrm{pH}$, brix and acidity were determined soon after the extraction only. The
$\mathrm{pH}$, total soluble solids and the acidity by means of ascorbic acid were 4.06, $15.2 \%$ and $0.66 \%$. Acidity was expressed in terms of ascorbic acid as this is the dominant acid in the fruit. The results showed that the pulp was not spoiled.

Pulp has bitter principle which hinders its exploitation in food industries. However Jansz (2006) stated that the bitterness can be reduced by freezing beyond $-20{ }^{\circ} \mathrm{C}$. Therefore pulp was kept in deep freezer at $-25{ }^{\circ} \mathrm{C}$ for about 48 hours to minimize its bitter taste and the bitterness of fresh pulp and frozen pulp was compared. It was experienced via tasting that the frozen pulp was less bitter than the fresh.

After the preparation of pulp for set and swiss style yoghurts, its texture, aroma and sweetness were improved and the colour remained as that of fresh pulp. Tartaric acid was added to reduce the $\mathrm{pH}$ closer to that of yoghurt. Citric acid and ascorbic acid were added as anti oxidants to prevent discolouration in the preparation. Sodium chloride was added as taste enhancer.

Palmyrah fruit pulp jelly prepared for the development of fruit jelly yoghurt was smooth and soft without any bubbles or foam on the top. The final $\mathrm{pH}$ of solution was 3.1 which is the most suitable $\mathrm{pH}$ for jelly to settlle off.

Palmyrah fFruit preserve was darker than the natural colour of the pulp but the texture was as same as that of jam. No air bubbles or sugar crystals formed and it was smooth and transparency. 


\subsection{Sensory evaluation of yoghurts}

Friedman test in Minitab was used to analyze the results of sensory evaluation to select the most preferred blend of each type of palmyrah fruit yoghurt.

\section{Palmyrah fruit pulp set yoghurt}

The preference of each sensory attributes of all palmyrah set yoghurts developed in the study were rated from 5 to 1 . Point 5 was given for like very much whilst point 1 was dislike very much.

TABLE 5: Sensory evaluation of set palmhyrah fruit yoghurt

\begin{tabular}{|l|c|c|c|c|c|}
\hline \multirow{2}{*}{$\begin{array}{c}\text { Sensory } \\
\text { attribut }\end{array}$} & \multicolumn{5}{|c|}{ Median score for the products } \\
\cline { 2 - 6 } & 175 & 101 & 115 & 142 & 107 \\
\hline Flavour & $4^{\mathrm{a}}(45.5)$ & $4^{\mathrm{a}}(44.0)$ & $\begin{array}{c}3^{\mathrm{b}} \\
(31.5)\end{array}$ & $\begin{array}{c}3^{\mathrm{b}} \\
(29.0)\end{array}$ & $\begin{array}{c}3^{\mathrm{b}} \\
(30.0)\end{array}$ \\
\hline Color & $\begin{array}{c}4^{\mathrm{a}} \\
(47.5)\end{array}$ & $\begin{array}{c}4^{\mathrm{a}} \\
(49.0)\end{array}$ & $3^{\mathrm{b}}(33.5)$ & $3^{\mathrm{b}}(25.5)$ & $\begin{array}{c}3^{\mathrm{b}} \\
(24.5)\end{array}$ \\
\hline $\begin{array}{l}\text { Appeara } \\
\text { nce }\end{array}$ & $\begin{array}{c}4^{\mathrm{a}} \\
(47.0)\end{array}$ & $\begin{array}{c}4^{\mathrm{a}} \\
(52.5)\end{array}$ & $3^{\mathrm{b}}(29.0)$ & $3^{\mathrm{b}}(26.5)$ & $\begin{array}{c}3^{\mathrm{b}} \\
(25.0)\end{array}$ \\
\hline Mouth & $\begin{array}{c}4^{\mathrm{a}} \\
\text { feel }\end{array}$ & $\begin{array}{c}4^{\mathrm{a}}(49.0) \\
\text { Texture }\end{array}$ & $\begin{array}{c}4^{\mathrm{b}}(27.5) \\
(52.5)\end{array}$ & $\begin{array}{c}4^{\mathrm{a}}(26.5) \\
(47.5)\end{array}$ & $\begin{array}{c}3^{\mathrm{b}} \\
(25.0)\end{array}$ \\
\hline Text & $3^{\mathrm{b}}(31.0)$ & $3^{\mathrm{b}}(26.0)$ & $\begin{array}{c}3^{\mathrm{b}} \\
(23.0)\end{array}$ \\
\hline
\end{tabular}

Same alphabets on means in a row show non-significant differences at the confidence level of $95 \%$. Sum of ranks are given along with the medians in the brackets.

175 - Set yoghurt with 5\% fruit pulp

101 - Set yoghurt with $7.5 \%$ fruit pulp

115 - Set yoghurt with $10 \%$ fruit pulp

142 - Set yoghurt with $12.5 \%$ fruit pulp

107 - Set yoghurt with $15 \%$ fruit pulp
Results (Table 5) shows that the products 175 and 101 scored same median 4 for all analyzed sensory attributes and no significant difference existed in-between the products for each attributes. Products 115, 142 and 107 showed significant different between the other two and among them, and scored less than 175 and 101. To select the best product between 175 and 101 the sum of rank had to be considered as the medians were same for each attribute. Product 175 has scored higher than the other for flavor, mouth feel and texture whereas the product 101 scored higher for colour and appearance. It would be rather good if the overall acceptability of the product was also analyzed. However as 175 scored higher for flavor, mouth feel and texture which indeed play in the success of product product 175 which contained $5 \%$ fruit pulp was selected as best.

\section{Palmyrah fruit pulp swiss style yoghurt}

Colour, flavour, appearance, mouthfeel and texture of each blend was rated from 5 to 1 where 5 was assigned to like very much and 1 was to dislike very much.

TABLE 6: Sensory evaluation of palmyrah fruit swiss style yoghurt

\begin{tabular}{|l|c|c|c|c|c|}
\hline \multirow{2}{*}{$\begin{array}{c}\text { Sensory } \\
\text { attributes }\end{array}$} & \multicolumn{5}{|c|}{ Median score for the products } \\
\cline { 2 - 6 } & 215 & 265 & 253 & 242 & 227 \\
\hline Flavour & $4^{\mathrm{a}}$ & $4^{\mathrm{a}}$ & $4^{\mathrm{a}}$ & $4^{\mathrm{a}}$ & $4^{\mathrm{a}}$ \\
& $(35.0)$ & $(35.0)$ & $(35.0)$ & $(33.5)$ & $(37.5)$ \\
\hline Color & $4^{\mathrm{a}}$ & $4^{\mathrm{a}}$ & $4^{\mathrm{a}}$ & $4^{\mathrm{a}}$ & $4^{\mathrm{a}}$ \\
& $(33.5)$ & $(39.0)$ & $(38.0)$ & $(32.0)$ & $(37.5)$ \\
\hline Appearanc & $3.85^{\mathrm{ab}}$ & $4.15^{\mathrm{a}}$ & $3.85^{\mathrm{bc}}$ & $3.65^{\mathrm{c}}$ & $3.75^{\mathrm{abc}}$ \\
$\mathrm{e}$ & $(38.0)$ & $(46.0)$ & $(33.5)$ & $(26.0)$ & $(36.0)$ \\
\hline Mouth feel & $3.9^{\mathrm{a}}$ & $4^{\mathrm{a}}$ & $3.9^{\mathrm{a}}$ & $3.9^{\mathrm{a}}$ & $3^{\mathrm{a}}$ \\
& $(39.0)$ & $(39.5)$ & $(35.0)$ & $(36.5)$ & $(30.0)$ \\
\hline Texture & $4^{\mathrm{ab}}$ & $4.3^{\mathrm{a}}$ & $4^{\mathrm{ab}}$ & $3^{\mathrm{b}}$ & $3.9^{\mathrm{ab}}$ \\
& $(34.5)$ & $(44.8)$ & $(36.5)$ & $(31.0)$ & $(34.9)$ \\
\hline
\end{tabular}


Same alphabets on means in a row show non-significant differences at the confidence level of $95 \%$. Sum of ranks are given along with the medians in the brackets.

\section{5 - Swiss style yoghurt with $5 \%$ fruit pulp}

265 - Swiss style yoghurt with $7.5 \%$ fruit pulp

253 - Swiss style yoghurt with $10 \%$ fruit pulp

242 - Swiss style yoghurt with $12.5 \%$ fruit pulp

227 - Swiss style yoghurt with $15 \%$ fruit pulp

The results of sensory evaluation (Table 6) revealed that the all products have scored the same median 4 for flavor, colour and mouth feel and no significant difference existed among them for each of those attributes. Product 265 scored the highest median and sum rank for appearance, mouth feel and texture. Also it was clear that product 265 scored the best for all sensory attributes. Therefore product 265 containing $7.5 \%$ fruit pulp was selected.

From the above results of both types of yoghurts, it could be noted that the selected swiss style yoghurt contained higher percent of pulp $(7.5 \%)$ than set yoghurt $(5 \%)$. Also the comments given by the panelists brought out that the consistency and appearance of swiss style yoghurt were better than that of set yoghurt and bitterness could not be sensed in swiss style yoghurt although the pulp was higher in that. About two or three days after the production set yoghurt showed water separation and the appearance became down. Therefore among the selected set and swiss style yoghurts, swiss style yoghurt with $7.5 \%$ fruit pulp was selected for further studies.

\section{Palmyrah fruit pulp jelly yoghurt}

Sensory evaluation revealed that both products scored 4.5 median to flavor, colour and texture and product 307 scored less than product 321 for appearance and mouth feel. Also the sum of ranks of product 321 were higher than those of 307 for all attributes. Therefore product 321 was selected finally (Table 7).

TABLE 7: Sensory evaluation of palmyrah fruit jelly yoghurt

\begin{tabular}{|l|c|c|}
\hline \multirow{2}{*}{$\begin{array}{c}\text { Sensory } \\
\text { attributes }\end{array}$} & \multicolumn{2}{|c|}{ Median score for the products } \\
\cline { 2 - 3 } & $321(5 \%$ of pulp) & $307(6 \%$ of pulp) \\
\hline Flavour & $4.5^{\mathrm{a}}(20.0)$ & $4.5^{\mathrm{a}}(19.0)$ \\
\hline Color & $4.5^{\mathrm{a}}(21.0)$ & $4.5^{\mathrm{a}}(18.0)$ \\
\hline Appearance & $4.5^{\mathrm{a}}(21.5)$ & $3.5^{\mathrm{b}}(16.5)$ \\
\hline Mouth feel & $4.5^{\mathrm{a}}(23.5)$ & $3.5^{\mathrm{b}}(15.5)$ \\
\hline Texture & $4.5^{\mathrm{a}}(20.0)$ & $4.5^{\mathrm{a}}(19.0)$ \\
\hline
\end{tabular}

Means in the each row followed by the same letters are not significantly different at $\mathrm{p}<0.05$. Sum of ranks are given along with the medians in the brackets.

\section{Palmyrah fruit pulp preserve yoghurt}

The results of sensory evaluation brought out that product with $10 \%$ of fruit pulp scored 4.5 median to flavor, colour and texture and mouth feel and the sum of ranks of product was higher than the other products with $5 \%$ and $7.5 \%$ fruit pulp and thus it (product with $10 \%$ of fruit pulp) was selected.

\subsection{Analysis of selected products}

Chemical analysis - $p H$, Brix and acidity $\mathrm{pH}$, acidity and total soluble solids of the all types of yoghurts selected in the sensory evaluation 
were analyzed to determine the chemical quality of them (Table 8).

TABLE 8: Analysis of $\mathrm{pH}$, acidity and total soluble solids of palmyrah fruit yoghurts selected in sensory evaluation

\begin{tabular}{|l|c|c|c|}
\hline \multicolumn{1}{|c|}{ Yoghurt } & $\mathbf{p H}$ & $\begin{array}{c}\text { Total } \\
\text { soluble } \\
\text { solids }\end{array}$ & $\begin{array}{c}\text { Acidity } \\
\left(\mathbf{g ~ 1 0 0 g}^{-1}\right)\end{array}$ \\
\hline Palmyrah fruit set yoghurt & 4.43 & 16.9 & $0.8 \pm 0.01$ \\
\hline $\begin{array}{l}\text { Palmyrah fruit swiss style } \\
\text { yoghurt }\end{array}$ & 4.36 & 18.6 & $0.9 \pm 0.03$ \\
\hline $\begin{array}{l}\text { Palmyrah fruit jelly } \\
\text { yoghurt }\end{array}$ & 4.60 & 21.3 & $0.97 \pm 0.01$ \\
\hline $\begin{array}{l}\text { Palmyrah fruit preserve } \\
\text { yoghurt }\end{array}$ & 4.33 & 23.6 & $1.01 \pm 0.01$ \\
\hline Control yoghurt & 4.27 & 16.2 & $0.79 \pm 0.02$ \\
\hline
\end{tabular}

SLS 824 Part 2: 1989 says that the acidity by means of lactic acid of a standard yoghurt should be between $0.8 \%$ and $1.25 \%$. Acidity of all products selected in the studiy was in between the limits specified in the standard. In contrast, the $\mathrm{pH}$ of the products were slightly higher than the optimum $\mathrm{pH}$ of 4.2 for coagulation. It may be due to the acidity of fruit pulp and the organic acids (citric acid, tartaric acid etc) added in preparation of pulp for the product developments.

\section{pH and brix of yoghurts with storage}

The results show that the $\mathrm{pH}$ and brix did not change much and they were in acceptable limits even after 18 days. Fruit jelly yoghurt showed the $\mathrm{pH}$ above 4.2. The change in $\mathrm{pH}$ and total soluble solids of each type of yoghurt were observed for 21 days (Figures 1, 2, 3 and 4).

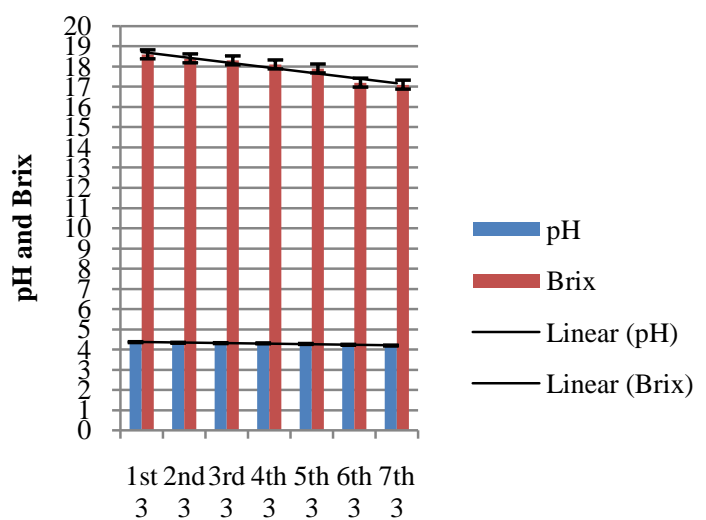

Time interval

Values are means of triplicates. Vertical bars indicate the standard errors.

FIGURE 1: Study on change of $\mathrm{pH}$ and brix of palmyrah fruit pulp swiss style yoghurt for 21 days

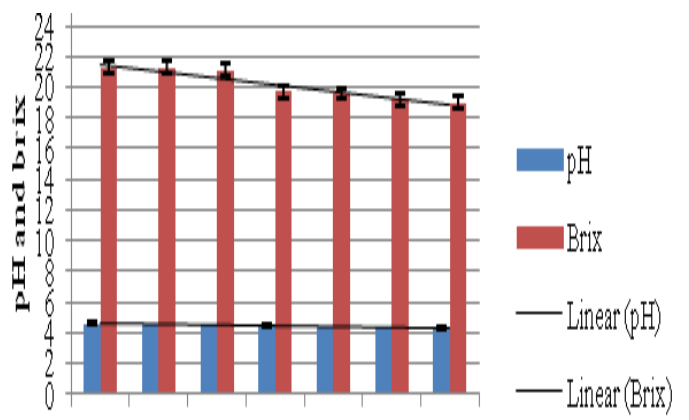

$15 t 3$ 2nd 3 3nd 3 4th 3 5th 36 th 3 7th 3

Time interval

Values are means of triplicates. Vertical bars indicate the standard errors.

FIGURE 2: Study on change of $\mathrm{pH}$ and brix of palmyrah fruit jelly yoghurt for 21 days 


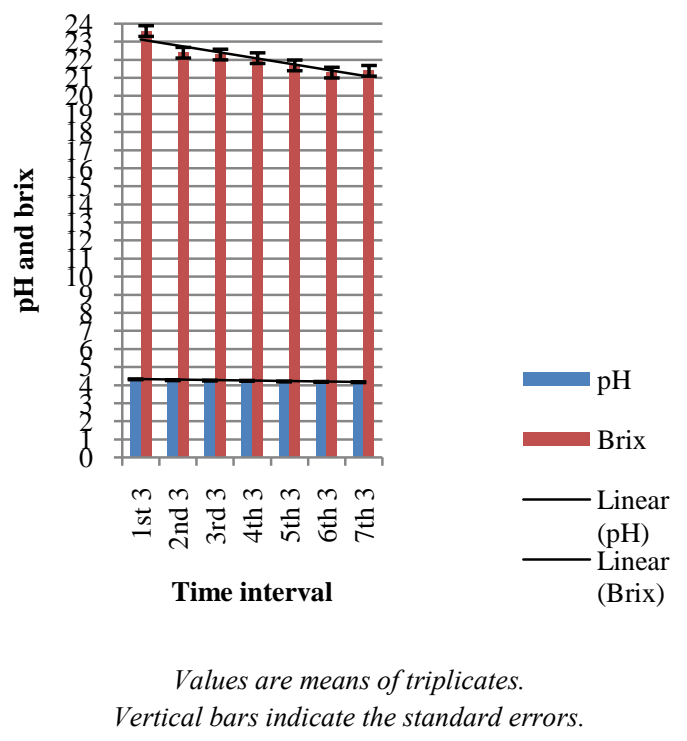

FIGURE 3: Study on change of $\mathrm{pH}$ and brix of palmyrah fruit preserve yoghurt for 21 days

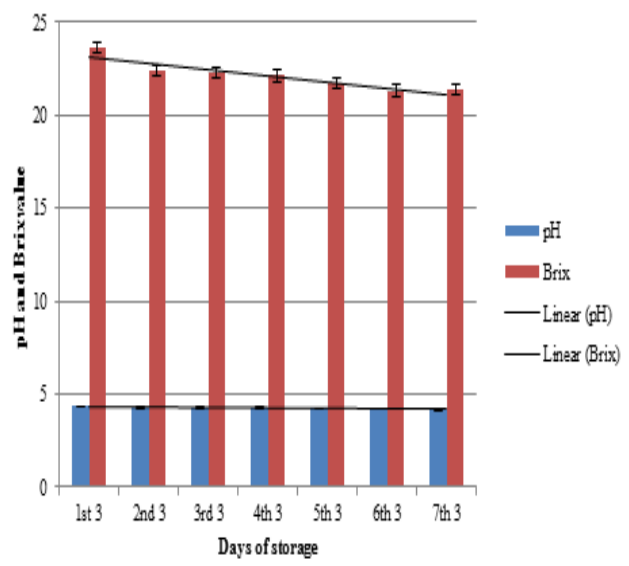

Values are means of triplicates.

Vertical bars indicate the standard errors.

FIGURE 4: Study on change of $\mathrm{pH}$ and brix of palmyrah fruit set yoghurt for 21 days

Although the characterisitcs of palmyrah fruit pulp set yoghurt were in the limits, separation of whey and water was observed on the third day from the development and the texture was too watery in set yoghurt. Therefore, the product was then discarded from further analysis.

The milk solids content (including the fat content) for yoghurt ranges from around $9 \%$ for low fat yoghurt to more than $20 \%$ for certain types of concentrated yoghurt. Many commercial yoghurt products have milk solids contents of 14 - $15 \%$ (Tamime and Robinson, 1999). The total solids content of milk can be increased by concentration processes, such as, evaporation under vacuum, and membrane processing (i.e., reverse osmosis and ultra filtration).

\section{Nutrient analysis of selected palmyrh fruit yoghurts in the study}

Codex Alimentarious Regulations for yoghurt (2008) indicates that the minimum milk protein content is $2.7 \%$ (except for concentrated yoghurt where the minimum protein content is $5.6 \%$ after concentration) and the maximum fat content is $15 \%$. The results (Table 9) show that the fat content of all products did not exceed 15 $\%$ and were between $0.71 \%$ and $2.47 \%$. Therefore, all palmyrah fruit pulp yoghurts can be categorized as low fat fruit yoghurts. The protein content of preserve yoghurt was lower than the limit as the preserve added for yoghurt was about $40 \%$ and thus the milk in the yoghurt was reduced drastically and the preserve contained almost $60 \%$ of sugar. It would be more informative about the nutrient value and medicinal benefits of the products if the analysis of crude fibre, dietary fibre and vitamin A is carried out. 
TABLE 9: Nutrient contents of developed palmyrah fruit pulp yoghurts

\begin{tabular}{|c|c|c|c|c|}
\hline \multirow[b]{2}{*}{ Nutrient } & \multicolumn{4}{|c|}{ Amount of nutrients $\left({\left.\mathrm{g} 100 \mathrm{~g}^{-1}\right)}^{-1}\right.$} \\
\hline & $\begin{array}{c}\text { Swiss } \\
\text { style } \\
\text { yoghurt }\end{array}$ & $\begin{array}{c}\text { Jelly } \\
\text { yoghurt }\end{array}$ & $\begin{array}{l}\text { Preserv } \\
\text { e fruit } \\
\text { yoghurt }\end{array}$ & $\begin{array}{l}\text { Commerci } \\
\text { al yoghurt } \\
\text { as control }\end{array}$ \\
\hline Protein & $\begin{array}{c}6.12 \pm \\
0.05\end{array}$ & $\begin{array}{c}7.77 \pm 0.0 \\
6\end{array}$ & $\begin{array}{c}2.48 \pm 0.0 \\
3\end{array}$ & $5.26 \pm 0.01$ \\
\hline Crude fat & $\begin{array}{c}0.71 \pm \\
0.01\end{array}$ & $\begin{array}{c}0.90 \pm 0.0 \\
5\end{array}$ & $\begin{array}{c}2.47 \pm 0.0 \\
3\end{array}$ & $0.80 \pm 0.05$ \\
\hline Moisture & $\begin{array}{c}55.59 \pm \\
0.3\end{array}$ & $\begin{array}{c}66.48 \pm 0 . \\
02\end{array}$ & $\begin{array}{c}61.38 \pm 0 \\
02\end{array}$ & $65.00 \pm 0.15$ \\
\hline Ash & $\begin{array}{c}0.56 \\
\pm 0.03\end{array}$ & $\begin{array}{c}0.53 \pm 0.0 \\
1\end{array}$ & $\begin{array}{c}0.92 \pm 0.0 \\
2\end{array}$ & $0.81 \pm 0.01$ \\
\hline $\begin{array}{c}\text { Acid } \\
\text { insoluble } \\
\text { ash }\end{array}$ & $\begin{array}{c}0.15 \pm 0 \\
02\end{array}$ & $0.46 \pm 0.0$ & $\begin{array}{c}0.29 \pm \\
0.01\end{array}$ & $0.29 \pm 0.01$ \\
\hline $\begin{array}{l}\text { Carbohydra } \\
\text { te + fibre }\end{array}$ & $\begin{array}{c}36.87 \pm \\
0.37\end{array}$ & $\begin{array}{c}23.86 \pm 0 . \\
09\end{array}$ & $\begin{array}{c}32.46 \pm 0 \\
08\end{array}$ & $27.84 \pm 0.12$ \\
\hline
\end{tabular}

Palmyrah fruit pulp contains provitamin A (32 ppm), vitamin C (285 ppm) and lycopene as well (Mohanajayelauxmy 1986). Apart from the nutritional benefits of pulp, it was discovered that Flabelliferin II was preventing the absorption of glucose into the blood stream with no adverse reactions (Janz 2006). Further it has anti glycemic activities, anti microbial activities and hypocholestremic acivities which are benefits for our health. $10-$ $12 \%$ pectin in pulp decrease cholesterol by 25 - $35 \%$ by binding bile salts and cholesterol (Jansz 2006).

Microbiological analysis. According to SLS 824 Part 2: 1989 E.coli, yeast and mold, lactic acid bacteria, and Salmonella should be analyzed howbeit since the media was not available at the time when the research was carried Salmonella will be checked in future works of the research. Total plate count test was done for skim milk powder, sugar, milk and potable water according to SLS 516 part 1, 1991. But bacterial growth was in acceptable range in potable water and bacterial growth was not observed in other ingredients. E. coli was absent in all products including control yoghurt. Yeast count of all products were not more than 1000 per gram and Mold did not exist in the selected products. Mostly the microbial contamination occurs during the process. Therefore implementation of hygienic practices during process will help reduce microbial contamination.

Organoleptic analysis. Texture, flavor and appearance were observed one in three days to determine the shelf life. They remained as fresh throughout the period of 21 days. But since the $\mathrm{pH}$ and acidity went beyond accepted level after 18 days observations were not taken as it will not contribute to determine shelf life further.

\section{Shelf life study}

$\mathrm{pH}$ and brix were measured once in three days to determine the shelf life of products for 21 days. At the same time, appearance, colour, smell and texture were observed by experienced persons. As discussed above in $\mathrm{pH}$ and brix change, the shelf life period was determined as 18 days without any preservatives at $4{ }^{\circ} \mathrm{C}$.

\section{CONCLUSION AND FURTHER WORK}

The optimized palmyrah fruit pulp concentrations for its set yoghurt, swiss style yoghurt, jelly yoghurt and preserve yoghurt were $5 \%, 7.5 \%, 6 \%$ and $10 \%(\mathrm{v} / \mathrm{v})$ respectively. All four products complied with Sri Lankan Standard 824:1989 and the $\mathrm{pH}$, brix and acidity of the final products were in 
acceptable ranges. The shelf life of the product was 18 days at $4^{\circ} \mathrm{C}$ without any preservatives.

However a complete analysis of nutrients including vitamin $\mathrm{A}$ and $\mathrm{C}$, phyto nutrients and dietary and crude fibres can give a complete nutrient profile and nutritional value of the developed products. Therefore, in the next season of fruits these constituents will be analysed. Also, the study on development of yoghurt with chemically preserved pulp will be studied. Consumer preference test and marketing survey should be done to improve its quality.

\section{REFERENCES}

AOAC International (2002). AOAC Official Methods of Analysis. (2002), $17^{\text {th }}$ Edition, ASSOCIATION OF OFFICIAL ANALYTICAL CHEMISTS Washington, USA.

BOGHRA, V. R. AND MATHUR O. N., (2000). Physico-chemical status of major milk constituents and minerals at various stages of shrikhand preparation. Journal of Food Science and Technology, 37: 111-115

FOOD AGRICULTURE ORGANIZATION AND WORLD HEALTH ORGANIZATION, CODEX ALIMENTARIOUS COMMISSION, (2003). Codex standard no 243 - 2003 Codex standard for fermented milk, United States of America

JANSZ, E. R., WICKREMASEKARA, N. T. AND SUMUDUNI, K. A. V. (2002). A Review of the Chemistry and Biochemistry of seed shoot flour and fruit pulp of the Palmyrah palm (Borassus flabellifer L.). Journal of National Science Foundation of Sri Lanka. 30(1\&2): 61-87.
JANSZ, E. R., (2006). Bioactivity of Palmyrah (Borrasus flabellifer) biomolecules, Nugegoda, Sri Lanka

JEYARATNAM, M. (1986). Studies on the Chemistry and Biochemistry of palmyrah products. M.Phil. Thesis. University of Jaffna, Sri Lanka. pp. 1-200

KAMRUZZAMAN M., ISLAM M .N, RAHMAN M. M., PARVIN S. AND. RAHMAN M. F, (2002). Evaporation rate of moisture from dahi (yoghurt) during storage at refrigerated condition. Pakistan Journal of Nutrition., 1: 209-211.

KUMAR, P. AND MISHRA H.N., (2004). Mango fortified set yoghurt: Effect of stabilizer addition of physicochemical, sensory and textural properties. Food Chemistry., 87: 501-507

MINISTRY OF LIVESTOCK AND RURAL COMMUNITY DEVELOPMENT, (2010). online available from http://www.livestock.gov.lk/site/index.php?1 ang=en,

PALMYRAH DEVELOPMENT BOARD, (2010). Annual Report of palmyrah, Jaffna

PATHBERIYA L. G, CHANDRIKA U. G (2003). Variation of bioactivity of fruit pulp of different cultivars of palmyrah research plan - National seminar on palmyrah research and development, palmyrah development board, Colombo, Sri Lanka 
PERDIGON, G., A.M. DE LEBLANC, J. VALDEZ AND M. RACHID, (2002). Role of yoghurt in the prevention of colon cancer. Eur. J. Clin. Nutr., 56: S65-S68

SIVAGNANASOTHY V., (2010). Accelerated palmyrah development work, Article on Daily news, (on line) 21st of September, 2010 available from http://archives.dailynews.lk/2010/09/21/fea1 6.asp. (Accessed on 20. 01. 2014)

SRI LANKA STANDARD INSTITUTE, (1991). Sri lankan Standard for microbiological analysis, SLS 516:Part 1, Total plate count, Sri Lanka

SRI LANKA STANDARD INSTITUTE, (2013). Sri Lankan Standard for microbiological analysis, SLS 516:Part 2-2, 2013 for Yeast and mold, Sri Lanka

TAMIME A.Y. AND. ROBINSON. R. K (1999). Yoghurt, Science and Technology International Journal of Dairy Technology, 61: 112-113.

THEIVENDRARAJAH. K. (2008). Palmyrah palm (Borrasus flabellifer) - A Monograph, Scarborough, Ontario, Canada. 